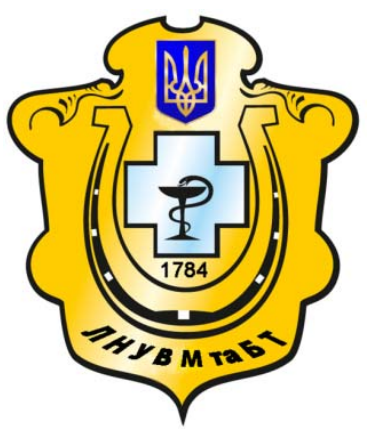

Науковий вісник Львівського національного університету ветеринарної медицини та біотехнологій імені С.3. Гжицького

Scientific Messenger of Lviv National University of Veterinary Medicine and Biotechnologies named after S.Z. Gzhytskyj

doi:10.15421/nvlvet7142

ISSN 2413-5550 print

ISSN 2518-1327 online

$\underline{\text { http://nvlvet.com.ua/ }}$

УДК 619:614.31:637.07

\title{
Контроль ліпофільних токсикантів у молоці з використанням мікробіологічного експрес-методу
}

\author{
М.С. Хімич, О.М. Горобей, В.3. Салата \\ khimichms@yandex.ua, gorobey@te.net.ua, salatavolod@ukr.net \\ Одеський державний аграрний університет, \\ вул. Пантелеймонівська, 13, м. Одеса, 65012, Україна; \\ * Львівський національний університет ветеринарної медицини та біотехнологій імені С.3. Гжицького, \\ вул. Пекарська, 50, м. Львів, 79010, Украӥна
}

\begin{abstract}
Сьогодні в світі існує чисельна кількість методів аналізу безпечності харчової продукиії (спектрометрія, фотометрія, хроматографія тощо). Але в нашій краӥні, мережа спеціалізованих лабораторій які були б в змозі забезпечити високоякісний і об'єктивний аналіз харчової продукиї, і досі дуже обмежена.

Також важливо пам'ятати, щуо існуючі хіміко-аналітичні методи нажаль неспроможні дати відповідь щодо загальноі реакиії організму рецииієнта на вплив досліджуваного об'єкту, щзо пов'язано з деякими факторами: в досліджуваному об'єкті можуть міститися токсиканти, вміст яких під час дослідження не передбачали, мало вивчені речовини, і головне, не враховується характер комбінованої дї токсикантів. Саме зважаючи на иі недоліки і сьогодні лишається актуальним визначення токсичності методом біотестування.

Метою наших досліджень було встановити можливість і ефективність застосування мікробіологічного експресметоду з використанням інфузорії Colpoda steinii для визначення токсичності молока збираного.

Дослідження токсичності проводились паралельно трьома методами: біопробою на лабораторних тварин (білих мишах) і мікробіологічними з використанням в якості тест-організму інфузорій Tetrachimena piriformis i Colpoda steinii.

Проведені дослідження встановили, щь дані щодо токсичності молока збираного визначеної запропонованим способом, ідентичні даним отриманим з використанням класичних методів.

Встановлено, щзо за сильної токсичності молока збираного результати дослідження при застосуванні інфузоріі C. steinii отримуємо вже за 3хв., а слабій токсичності або нетоксичності - за 1 год.

Ключові слова: харчова продукиія, молоко, якість, безпека, безпечність, токсичність, біотестування, експрес-метод, тест-об'єкт, інфузорії, Colpoda steinii.
\end{abstract}

\section{Контроль липофильных токсикантов в молоке с использованием микробиологического экспресс-метода}

\author{
М.С. Химич, А.М. Горобей, В.З. Салата \\ khimichms@yandex.ua,gorobey@te.net.ua, salatavolod@ukr.net \\ Одесский государственный аграрный университет, \\ ул. Пантелеймоновская, 13, г. Одесса, 65012, Украина \\ * Львовский национальный университет ветеринарной медицины и биотехнологий имени С.3. Гжицкого, \\ ул. Пекарская, 50, г. Львов, 79010, Украина
}

\begin{abstract}
Сегодня в мире существует многочисленная количество методов анализа безопасности пищевой продукиии (спектрометрия, фотометрия, хроматография и т.д.). Но в нашей стране, сеть специализированных лабораторий которые были бы в состоянии обеспечить качественный и объективный анализ пищевой продукции, и до сих пор очень ограничено.
\end{abstract}

Khimich, M.S., Gorobey, O.M., Salata, V.Z. (2016). Control lipophilic toxins in milk using microbiological express methods. Scientific Messenger LNUVMBT named after S.Z. Gzhytskyj, 18, 3(71), 186-189. 
Также важно помнить, что существуюшие химико-аналитические методы сожалению не могут дать ответ по общей реакции организма реципиента на воздействие исследуемого объекта связано с некоторыми факторами: в исследуемом объекте могут содержаться токсиканты, содержание которых во время исследования не предполагали, мало изучены вещества, и главное, не учитывается характер комбинированного действия токсикантов. Именно учитьвая эти недостатки и сегодня остается актуальным определение токсичности методом биотестирования.

Целью наших исследований было установить возможность и эффективность применения микробиологического экспресс-метода с использованием инфузории Colpoda steiniі для определения токсичности молока.

Исследование токсичности проводились параллельно тремя методами: биопробы на лабораторных животных (бельх мышиах) и микробиологическим с использованием в качестве тест-организма инфузорий Tetrachimena piriformis и Colpoda steinii.

Проведенные исследования установили, что данные по токсичности молока сгущенного определенной предложенным способом, идентичны данным полученным с использованием классических методов.

Установлено, что при сильной токсичности молока результаты исследования при применении инфузории С. stеіпіі получаем уже за 3 мин., а слабой токсичности или нетоксичности - по 1 ч.

Ключевые слова: пищевая продукция, молоко, качество, безопасность, безопасность, токсичность, биотестирования, экспресс-метод, тест-объект, инфузории, Colpoda steinii.

\title{
Control lipophilic toxins in milk using microbiological express methods
}

\author{
M.S. Khimich, O.M. Gorobey, V.Z. Salata \\ khimichms@yandex.ua, gorobey@te.net.ua, salatavolod@ukr.net \\ Odessa State Agrarian University, \\ Panteleimonovska Str., 3, Odessa 65012, Ukraine; \\ Lviv National University of Veterinary Medicine and Biotechnologies named after S.Z. Gzhytskyi, \\ Pekarska Str., 50, Lviv, 79010, Ukraine
}

In recent years, Ukraine is constantly increasing livestock production. But at the same time, in many modern industries, veterinary and sanitary control of food is on insufficient or non-existent. In this connection the trading network can get dangerous foods for consumers.

Today in the world there are numerous number of methods of analysis of food safety (spectrometry, photometry, chromatography, etc.). But in our country, a network of specialized laboratories which would be able to provide high-quality and objective analysis of the food is still very limited.

It is also important to remember that the current chemical-analytical methods unfortunately unable to answer the general reaction of the organism to influence the recipient of the object, which is associated with several factors: the test object may contain toxicants with content during the study not predicted poorly understood substances, and importantly, is not considered character combined action of toxicants. That despite these shortcomings and remains an important method of determining the toxicity bioassay.

The aim of our research was to establish the feasibility and effectiveness of the rapid microbiological method using ciliates Colpoda steinii to determine the toxicity of skimmed milk.

Toxicity studies were carried out in parallel by three methods: bioassay in laboratory animals (white mice) and microbiological using as a test organism ciliates Tetrachimena piriformis and Colpoda steinii.

The proposed method of using as a test organism ciliates Colpoda steinii, including the preparation of test culture ciliates Colpoda steinii, sampling investigational product, extracting samples of chemically pure acetone, filtering selected extract dilution leachate solution rod-Lozinski, introducing the filtrate into a test culture ciliates, temperature control resulting mixture at a temperature of $+26 \ldots+28{ }^{\circ} \mathrm{C}$ and determine the toxicity of the investigational product, observing the vital functions of ciliates during incubation.

The research found that data on the toxicity of skimmed milk a certain prescribed manner identical data obtained using classical methods.

Established that the strong toxicity of skimmed milk in the application of research results ciliates $C$. steinii get already at 3 min. And weak toxicity or netoksychnosti - 1 hour.

Key words: food products, milk, quality, safety, toxicity, bioassay, express (rapid) method, test object, ciliates, Colpoda steini

\section{Вступ}

Одним з основних завдань ветеринарної медицини $€$ забезпечення якості і безпечності продуктів харчування.

В останні роки в Україні постійно збільшується виробництво продукції тваринництва. Але в той же час, на багатьох сучасних виробництвах, ветеринарно-санітарний контроль харчової продукції знаходиться на недостатньому рівні або взагалі відсутній. В зв'язку з чим до торгової мережі можуть потрапляти харчові продукти небезпечні для споживача (Kasyanchuk, 2000).
Сьогодні в світі існує чисельна кількість методів аналізу безпечності харчової продукції. Зокрема для визначення вмісту в харчових продуктах токсичності використовують такі надточні методи як спектрометрія, фотометрія, хроматографія тощо. Але в нашій країні, не зважаючи на постійне реформування структури служби ветеринарної медицини, посилення вимог щодо безпечності і якості харчових продуктів та наближення їх контролю до європейських вимог, все ще лишаються недоліки і недосконалість нормативно-правової бази 3 цих питань. Економічний стан в якому перебуває країна, також не сприяє розширенню мережі спеціалізованих лабораторій які були б в змозі 
забезпечити високоякісний і об'єктивний аналіз харчової продукції (Kasyanchuk, 2000; Dubinina et al., 2007).

Також важливо пам'ятати, що існуючі хімікоаналітичні методи здатні дати об'єктивний результат при визначені якісного і кількісного вмісту в досліджуваному об'єкті окремих токсикантів. Натомість, вони неспроможні дати відповідь щодо реакції організму людини на вплив досліджуваного об'єкту, вцілому. Ця особливість пов'язана з тим, що в досліджуваному об'єкті можуть міститися токсиканти, вміст яких під час дослідження не передбачали, або мало вивчені речовини. Крім того, хіміко-аналітичні методи не передбачають характер комбінованої дії токсикантів, що відіграє важливу роль в загальному прояві токсичного ефекту (Pinigin, 1986; Manenko and Ivanova, 1988; Dubinina et al., 2007).

Зважаючи на зазначені аспекти, і сьогодні вченіексперти вважають, що не можна повною мірою відмовитись від біотестування. Адже саме метод біотестування з великою достовірністю дозволяє визначити ступінь загальної токсичності досліджуваного об'єкту (Vinokhodov, 2007).

Сьогодні існує чисельна кількість методів біотестування на різних тест-обєктах, але враховуючи біоетичні норми, зважаючи на межі чутливості та час реакції, оптимальним тест-об'єктом є інфузорії (Vinokhodov et al., 2006; Khimich, 2014).

Враховуючи вищевикладене метою наших досліджень було встановити можливість і ефективність використання інфузорії Colpoda steinii для визначення токсичності молока збираного.

\section{Матеріал і методи досліджень}

Дослідженню підлягали зразки молока збираного. Дослідження токсичності проводились паралельно трьома методами - біопроба на лабораторних тварин (білі миші ) і мікробіологічні методи з використанням в якості тест-організму інфузорій Tetrachimena piriformis i Colpoda steinii.

Дослідження на білих мишах та інфузорії Tetrachimena piriformis проводили відповідно до діючих методик.

При досліджені з використанням інфузорії Colpoda steinii, за основу було взято «Спосіб визначення токсичності риби» (Kovbasenko et al., 2014).

Підготовка тест-культури інфузорій. У флакони iз культурою Colpoda steinii, заливали по $2 \mathrm{~cm}^{3}$ поживного середовища за 24 год до проведення аналізу. Флакони закривали ватно-марлевими пробками та витримували в термостаті за температури $+26 \ldots+28^{\circ} \mathrm{C}$. Безпосередньо перед використанням флакони витримували в добре освітленому приміщені протягом 10хв. і проводили контроль активності культури.

Підготовка зразка для аналізу. Відібраний зразок об'ємом 10 см³ $^{3}$, екстрагували хімічно чистим ацетоном який додавали в об'ємі $10 \mathrm{~cm}^{3}$, струшували протягом 20 хв. і фільтрували екстракт крізь паперовий фільтр. Відбирали $0,5 \mathrm{~cm}^{3}$ ацетонового екстракту i розбавляли розчином Лозина-Лозинського в об'ємі 60 $\mathrm{cm}^{3}$.

Проведення аналізу. Отриманий розчин ацетонового екстракту в об'ємі $2 \mathrm{~cm}^{3}$ вносили до підготовленої тест-культури інфузорій.

В якості позитивного контролю використовували мікотоксин Т-2, який вводили в зразок молока 3 розрахунку 0,1 мг/мл. В якості негативних контролів використовували два зразки: 1 - додавали $2 \mathrm{~cm}^{3}$ суміші ацетону і розчину Лозина-Лозинського у співвідношенні 1:6; 2 - 2 см $^{3}$ дистильованої води.

Закривали флакони ватно-марлевими пробками i термостатували при температурі $+26 \ldots+28^{\circ} \mathrm{C}$, де витримували протягом всього досліду.

Через 3 хв. флакони виймали і досліджували активність колоди. У разі загибелі інфузорій у дослідному, або негативних контрольних флаконах дослід припиняли. Якщо більшість інфузорій були живі продовжували спостереження протягом 1 год.

Оцінку ступеня токсичності дослідних зразків проводили відповідно до запропонованої шкали (табл. 1).

Таблиия 1

\begin{tabular}{|c|c|}
\hline $\begin{array}{c}\text { Ступінь } \\
\text { токсичності }\end{array}$ & Показники \\
\hline Токсично & $\begin{array}{c}\text { Загибель } 100 \% \text { колпод настає впро- } \\
\text { довж 3хв }\end{array}$ \\
\hline Слаботоксично & $\begin{array}{c}\text { Впродовж } 1 \text { год. загинуло менше } \\
80 \% \text { колпод }\end{array}$ \\
\hline Нетоксично & $\begin{array}{c}\text { Впродовж } 1 \text { год. всі колподи зали- } \\
\text { шаються рухливими та інтенсивність } \\
\text { росту більше } 90 \%\end{array}$ \\
\hline
\end{tabular}

\section{Результати та їх обговорення}

Проведені дослідження встановили, що дані щодо токсичності молока збираного визначеної запропонованим мікробіологічним експрес-методом, 3 використанням в якості тест-об'єкту інфузорії С. steinii, ідентичні даним отриманим 3 використанням класичного i мікробіологічного (з використанням інфузорії Т. Piriformis) методів ( табл. 2).

Встановлено, що за сильної токсичності молока збираного результати дослідження при застосуванні інфузоріï C. steinii отримуємо вже за 3 хв., а слабій токсичності або нетоксичності - за 1 год.

\section{Висновки}

1. Визначення токсичності молока збираного мікробіологічним методом з використанням інфузорії С. steinii в якості тест-об'єкту, дає результат ідентичний результату отриманому при досліджені класичним методом на лабораторних тваринах і мікробіологічним методом з використанням інфузорії T. piriformis.

2. Застосування мікробіологічного метода з використанням інфузорії С. steinii в якості тест-об'єкту, скорочує тривалість дослідження на токсичність до 1 години. 
Токсичність молока збираного залежно від методу досліджень (n-5)

\begin{tabular}{|c|c|c|c|c|}
\hline \multirow{3}{*}{ Зразки } & \multicolumn{4}{|c|}{ Тест-об'єкти } \\
\hline & \multirow{2}{*}{ білі миші } & \multirow{2}{*}{ Tetrachimena piriformis } & \multicolumn{2}{|c|}{ Colpoda steinii } \\
\hline & & & 3 XB. & 1 год \\
\hline Позитивний контроль & ++++ & ++++ & ++++ & \\
\hline Негативний контроль 1 & - & - & - & - \\
\hline Негативний контроль 2 & - & - & - & $\longrightarrow$ \\
\hline \multirow{5}{*}{ Дослідні зразки } & - & - & $\longrightarrow$ & $\longrightarrow$ \\
\hline & $\longrightarrow+$ & $\longrightarrow+$ & $\longrightarrow$ & -++ \\
\hline & - & - & $\longrightarrow$ & -+ \\
\hline & -++ & -++ & - & -+++ \\
\hline & ++++ & ++++ & ++++ & \\
\hline
\end{tabular}

Примітка: «+» загибель мишей, лізіс інфузорій; «-» відсутність загибелі мишей і лізісу інфузорій.

Перспективи подальших досліджень. Представлені дані є частиною наших дослідів щодо можливості застосування мікробіологічного методу з використанням інфузорії C. steinii при визначені широкого спектру ліпофільних токсикантів в продуктах тваринного походження

\section{Бібліографічні посилання}

Kasyanchuk, V.V. (2000). Suchasni mijnarodni vimogi shodo bezpeki kharchovikh produktiv. Veterinarna medicina Ukraini. 5, 18-19 (in Ukrainian).

Dubinina, A.A., Malyk, L.P., Selyta, G.A. (2007). Toksichni rechovini $\mathrm{u}$ kharchovikh produktakh ta metodi ikh viznachennya. K.: Profesional (in Ukrainian).

Pinigin, M.A. (1986). O ponyatii "kharakter kombinirovannogo deistviya" kak osnove gigienicheskoi ocenki. Gigiena i sanitariya. 1, 45-48 (in Russian).

Manenko, A.K., Ivanova, O.P. (1988). Sravnitelnaya kharakteristika metodov matematicheskoy ocenki kharaktera kombinirovannogo deicnviya dvukh s bolee povrejdayshikh khimiceskikh faktorov pri odnov- remennom I posledovatelnom vvedenii v ostrich opitakh. Gigiena i sanitariya. 11, 55-58 (in Russian).

Vinokhodov, D.O. (2007). Nauchnie osnovi biotestirovaniya $s$ ispolzovaniem infuzoriy : avtoref. dis. na soiskanie uch. stepeni doc. biolog. nauk : spec. 03.00.23 «Biotekhnologiya». SPb (in Russian).

Vinokhodov, V.O., Vinokhodov, D.O., Polyakova, N.L. (2006). Noviy expres-metod opredeleniya toksichnosti myasoproduktiv. Praktik. 2, 26-31 (in Russian).

Khimich, M.S. (2014). Kontrol bezpechnosti ribi $\mathrm{z}$ vikoristannyam mikrobiologichnogo expres-metodu. Naukoviy visnik Lvivskogo nacionalnogo universitetu veterinarnoi medicini ta biotekhnologiy. Lviv. 16, 3(60), 418-423 (in Ukrainian).

Kovbasenko, V.M., Khimich, M.S., Naidich, O.V., Pchelinska, L.V., Baran, M.M. (2014). Pat. 96714, Ukraina, MPK ${ }^{6}$ G 01 N 33/02, C 12 Q 1/02, C 12 R 1/90 Sposib viznachennya toksichnosti ribi /- № u 201410274 ; zayav. 19.09.2014; opubl. 10.02.2015, Byl. №3 (in Ukrainian).

Стаття надійшла до редакиії 7.10.2016 